\title{
Yield Gap Analysis, Economics, Adoption and Horizontal Spread of Tomato Cultivation through Front Line Demonstration in Seoni District of Madhya Pradesh, India
}

\author{
N.K. Singh ${ }^{1 *}$, Mrigendra Singh ${ }^{2}$, Sharad Bisen ${ }^{3}$ and A.P. Bhandarkar ${ }^{1}$ \\ ${ }^{1}$ Krishi Vigyan Kendra, Seoni (M.P.), India \\ ${ }^{2}$ Krishi Vigyan Kendra, Shahdol (M.P.), India \\ ${ }^{3}$ Collage of Agriculture, Waraseoni Balaghat (M.P.), India \\ *Corresponding author
}

\section{A B S T R A C T}

\begin{tabular}{|l|}
\hline K e y w o r d s \\
Tomato, FLDs, Adoption \\
level, Yield, Economics, \\
Technology and \\
Extension gap
\end{tabular}

Tomato (Solanum lycopersicum $\mathrm{L}$ ) is one of the major vegetable crops cultivated in India, which plays a major role in supplementing the income of small and marginal farmers of Seoni district of Madhya Pradesh. The front line demonstrations (FLDs) were conducted on farmer's field in Seoni district of Madhya Pradesh for three consecutive years (2014-15 to 2016-17) at two adopted villages. Prevailing farmer's practices were treated as control for comparison with demonstrated technology. The result of FLDs conducted by Krishi Vigyan Kendra, Seoni in tomato crop shows a greater impact on farmer's livelihood due to significant increase in yield over local check. The extension gap ranged between 78.78 and $136.08 \mathrm{q} / \mathrm{ha}$, whereas the trend of technology gap ranged between 394.58 and $424.71 \mathrm{q} / \mathrm{ha}$. The benefit cost ratio (B: C) was recorded higher i.e. 2.44 to 2.90 under demonstrated practice, while it was 1.82 to 2.40 under check practice. The results of improved technological intervention brought out 28.47 to $71.92 \%$ increase in yield of tomato. The overall adoption level of demonstrated tomato production technology was increased about $283 \%$ due to FLDs, if appropriate package and practices are followed.

\section{Introduction}

Realizing the importance of dissemination of technological information in the changing scenario of food and nutritional security, the Indian Council of Agricultural Research, New Delhi has established a wide network of Krishi Vigyan Kendras (KVKs) in the country aiming at assessment refinement and demonstration of technologies or products. It was also envisaged that technology assessed by the KVKs will be act as model for the line departments and as a catalyst to improve the existing systems for better delivery mechanism. The KVKs organize front line demonstrations (FLDs) which aim at demonstrating newly released and pre-released production technologies of cereals, pulses and vegetables on farmer's fields. KVKs are playing strategic role in technology backstopping, knowledge management and advisory to the different stakeholders like farmers, farm women, rural youths and extension personnel. Tomato considered as a 
'protective food' is being extensively grown as annual vegetable crop all over the world. It is mostly used for both fresh market and processing. It is an important source of vitamin $\mathrm{A}$, vitamin $\mathrm{C}$ and lycopene that are potent antioxidants. In India, tomato is cultivated more extensively in comparison to other vegetables. Currently, India is producing 11.1 per cent of world tomato and ranks second in production after China. But, the productivity is just 24.34 tons per ha which is less than the world average of 33.99 tons per ha. One of the reasons for this low productivity is low access of Indian farmers to the modern technologies. In India, tomato is produced on an area of 809.00 thousand hectare with a production of 19697 thousand million tons (NHB, 2017).

In India it is extensively grown throughout the country as a cool season vegetable crop for its ripe fruits. The main tomato producing states are Madhya Pradesh, Odisha, Karnataka, Andhra Pradesh, Telangana, West Bengal, Bihar, Maharashtra and Chhattisgarh. In Madhya Pradesh, tomato is cultivated in about 100.00 thousand ha area with a total production of about 3102.00 thousand tons and average productivity being 31.02 tons /ha which is $27 \%$ higher than the national average of 24.34 tons /ha. In Seoni district of Madhya Pradesh, the average productivity of tomato is 28.71 tons /ha which is $17.95 \%$ higher than the national average (NHB, 2017). In Seoni district of Madhya Pradesh, tomato could not achieved its yield potentials mostly due to use of low yielding old varieties, imbalanced use of fertilizers and injudicious use of plant protection measures for control of bacterial wilt, early blight and tomato leaf curl diseases. There are ample scopes for improvement of tomato productivity to raise the income of the farming community of the district. Further, the resource poor farmers are very reluctant towards proper scientific management of the crop. But, the tomato productivity in Seoni district can be enhanced by adopting cost and input efficient technologies, and the bridge in yield gap may be level up to certain extent.

\section{Materials and Methods}

The study was carried out by JNKVV, Krishi Vigyan Kendra Seoni, (M.P.) during Rabi season from 2014-15 to 2016-17 (three consecutive years) at the farmers field of two adopted villages namely Dheka and Marjhor of Seoni district. During these three years of study, an area of 6.4 ha was covered under FLDs with active participation of 31 farmers. Before conducting FLDs, a list of farmers was prepared from group meetings and specific skill training was imparted to the selected farmers regarding different aspects of cultivation. The difference between the demonstration package and existing farmer's practices are mentioned in table 1 .

In demonstration plots, use of quality seeds of improved hybrid Arka Rakshak procured from IIHR, Bangalore were sown in nursery and transplanted in raised bed with using balanced fertilization and timely application of weedicide and pesticides. The traditional practices were taken as a local check. The data on output were collected from FLD plots as well as control plots, and finally the extension gap, technology gap, technology index, economics of demonstration along with the benefit cost ratio were worked out. The demonstrated trials were regularly monitored and necessary data related to all necessary traits of the new varieties were collected. In addition to this, data on traditional practices followed by the farmers were also collected. Technology gap, extension gap and technology index were worked out as per formula suggested by Samui et al., (2000) and Dayanand et al., (2012) as given below:

Technology gap $=$ Potential yield $(\mathrm{P} 1)$ Demonstration yield (D1); 
Extension gap = Demonstration yield (D1) Farmers yield (F1) and

Technology index = ----------- x 100

However, data about adoption and horizontal spread of technologies were collected from the farmers with the help interview schedule. Data were subjected to suitable statistical methods. The following formulae were used to assess the impact on different parameters of tomato crop.

Impact on Yield

Yield of Demonstrated plotYield of Control Plot

$(\%$ increase over control $)=$-------------- X 100 Yield of Control Plot

No of Adopters after Demonstration No of Adopters before Demonstration Impact on Adoption

$(\%$ Change $)=$ x 100

No of Adopters before Demonstration

After area (ha) - Before area (ha) Impact on Horizontal

$$
\begin{aligned}
\text { Spread (\% Change) }= & \text {------------- x } 100 \\
& \text { Before area (ha) }
\end{aligned}
$$

\section{Results and Discussion}

A perusal of data (Table 2) indicates that the yield of tomato increased successively over the years in demonstration plots. The average fruit yield ranged from 325.29 to $355.42 \mathrm{q} / \mathrm{ha}$ with the increase in percentage of yield ranged between 28.47 to 71.92 during three years of the study. The result revealed the positive effects of FLD over the existing practices as it enhanced the yield of tomato in Seoni district of Madhya Pradesh. The extension gap ranging between 78.78 to $136.08 \mathrm{q} /$ ha during the period of study emphasizes the need to educate the farmers through various means for the adoption of improved agricultural production to reverse the trend of wide extension gap.

The trend of technology gap ranging between 394.58 and $424.71 \mathrm{q} / \mathrm{ha}$ reflected the farmer's cooperation in carrying out such demonstration with encouraging results in subsequent years. The technology gap observed may be attributed to the dissimilarity in soil fertility status and weather condition. Similar findings were also recorded by Singh et al., (2016)

The technology index showed the feasibility of the evolved technology at the farmer's field. The lower the value of technology index, the more is the feasibility of the technology. As such, the reduction in technology index from $52.61 \%$ during 2016-17 to $56.62 \%$ during 2014-15 exhibited the feasibility of the demonstrated technology in this region.

\section{Benefit- Cost (B: C) ratio}

In order to ascertain the economic feasibility of the demonstration technologies over and above the control, some economic indicators like cost of cultivation, net return and $\mathrm{B}$ : $\mathrm{C}$ ratio was worked out. The economic viability of improved demonstrated technology over farmers practice was calculated depending on prevailing price of inputs and output cost and represented in term of $\mathrm{B}$ : $\mathrm{C}$ ratio (Table 3 ). It was found that the cost of production of tomato under demonstration varied from Rs 66578 to 79546 /ha with an average of Rs 74878 as against Rs 51800 to 69123/ha with an average of Rs 62837 under control. The additional cost increased in the demonstration was mainly due to more cost involved in balanced fertilizer, procurement of improved hybrid and IPM practices. The data revealed that the net return from the demonstration were substantially higher than control plots. 
Table.1 Level of use and gap in adoption of tomato technologies in study area

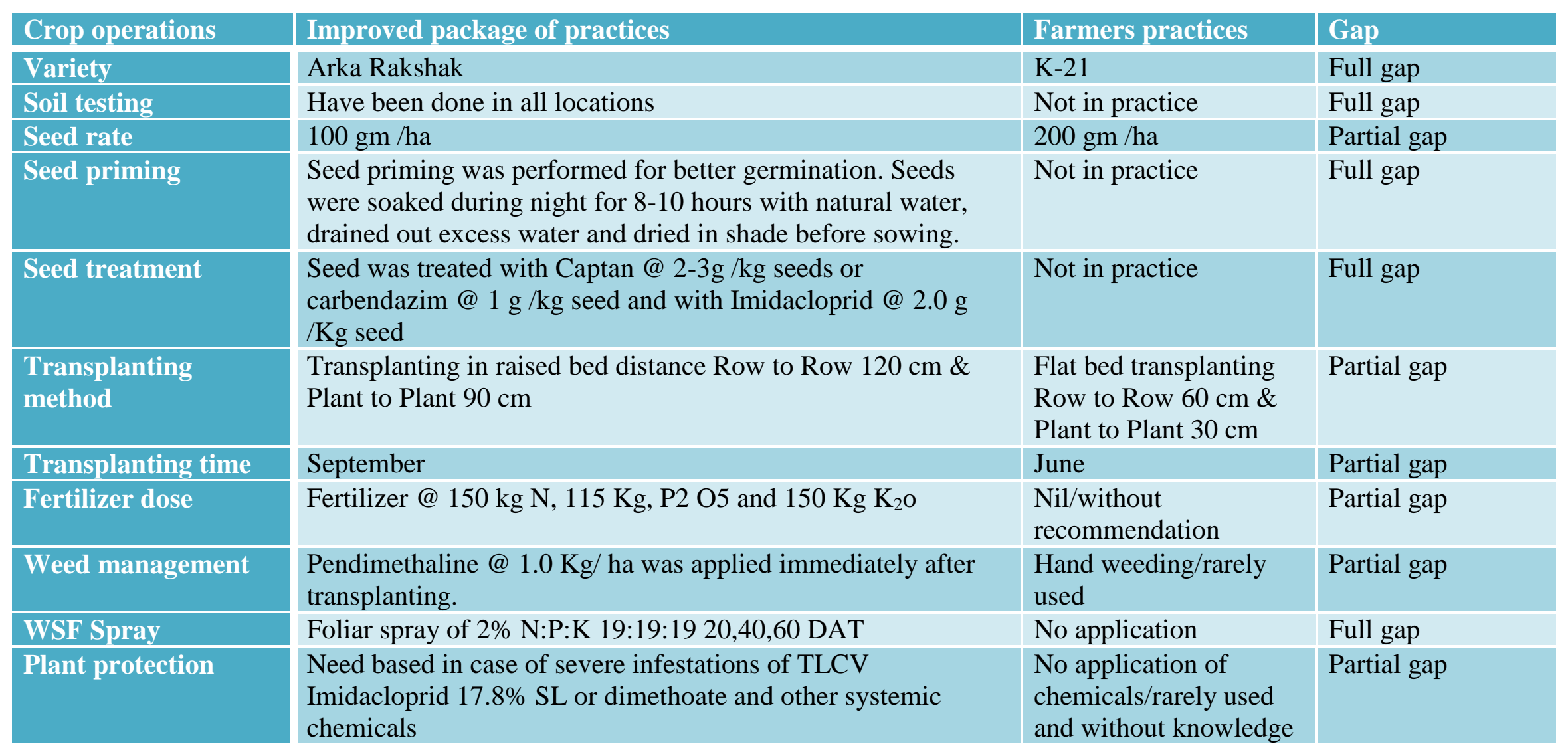

Table.2 Productivity, technology gap, extension gap and technology index in tomato (cv Arka Rakshak) Under FLDs

\begin{tabular}{|c|c|c|c|c|c|c|c|c|c|}
\hline \multirow[t]{2}{*}{ Year } & \multirow[t]{2}{*}{ Area (ha) } & \multirow{2}{*}{$\begin{array}{l}\text { No. of } \\
\text { farmers }\end{array}$} & \multicolumn{3}{|c|}{ Fruit yield (q/ha) } & \multirow{2}{*}{$\begin{array}{l}(\%) \text { Increase } \\
\text { in } \\
\text { productivity }\end{array}$} & \multirow{2}{*}{$\begin{array}{l}\text { Technology } \\
\text { gap (q/ha) }\end{array}$} & \multirow{2}{*}{$\begin{array}{l}\text { Extension } \\
\text { gap (q/ha) }\end{array}$} & \multirow{2}{*}{$\begin{array}{l}\text { Technology } \\
\text { index }(\%)\end{array}$} \\
\hline & & & Potential & Demonstration & Control & & & & \\
\hline 2014-15 & 2.0 & 10 & 750.00 & 325.29 & 189.21 & 71.92 & 424.71 & 136.08 & 56.62 \\
\hline 2015-16 & 2.4 & 11 & 750.00 & 352.17 & 263.70 & 33.54 & 397.83 & 88.47 & 53.04 \\
\hline $2016-17$ & 2.0 & 10 & 750.00 & 355.42 & 276.64 & 28.47 & 394.58 & 78.78 & 52.61 \\
\hline
\end{tabular}


Table.3 Cost of cultivation (Rs/ha), net return (Rs/ha) and benefit: cost ratio of tomato as affected by demonstration and local practices control

\begin{tabular}{|c|c|c|c|c|c|c|c|c|c|c|}
\hline \multirow[t]{2}{*}{ Year } & \multicolumn{2}{|c|}{ Yield (q/ha) } & \multicolumn{2}{|c|}{$\begin{array}{c}\text { Cost of Cultivation } \\
\text { (Rs/ha) }\end{array}$} & \multicolumn{2}{|c|}{$\begin{array}{l}\text { Gross Return } \\
\text { (Rs/ha) }\end{array}$} & \multicolumn{2}{|c|}{$\begin{array}{l}\text { Net Return } \\
\text { (Rs/ha) }\end{array}$} & \multicolumn{2}{|c|}{$\begin{array}{c}\text { Benefit Cost ratio } \\
\text { B:C Ratio }\end{array}$} \\
\hline & $\begin{array}{l}\text { Demonstrati } \\
\text { on }\end{array}$ & Control & $\begin{array}{l}\text { Demonstrati } \\
\text { on }\end{array}$ & Control & Demonstration & Control & Demonstration & Control & Demonstration & $\begin{array}{c}\text { Contro } \\
\text { l }\end{array}$ \\
\hline 2014-15 & 325.29 & 189.21 & 66578 & 51800 & 162645 & 94605 & 96067 & 42805 & 2.44 & 1.82 \\
\hline $2015-16$ & 352.17 & 263.70 & 78512 & 67589 & 211302 & 158220 & 132790 & 90631 & 2.69 & 2.34 \\
\hline 2016-17 & 355.42 & 276.64 & 79546 & 69123 & 231023 & 165984 & 151477 & 96861 & 2.90 & 2.40 \\
\hline
\end{tabular}

Table.4 Impact of Front Line Demonstration (FLDs) on adoption of tomato production technology

\begin{tabular}{|c|c|c|c|c|}
\hline \multirow[b]{2}{*}{ Technology } & \multicolumn{2}{|c|}{ Number of Adopters ( $N=31)$} & \multirow{2}{*}{$\begin{array}{c}\text { Change in No. } \\
\text { of Adopter }\end{array}$} & \multirow{2}{*}{$\begin{array}{c}\text { Impact } \\
(\% \text { Change) }\end{array}$} \\
\hline & Before Demonstration & After Demonstration & & \\
\hline Land preparation and FYM application & 19 & 31 & 12 & 63.15 \\
\hline Recommended hybrid & 09 & 29 & 20 & 222.22 \\
\hline Seed rate & 05 & 30 & 25 & 500.00 \\
\hline Transplanting in raised bed & 11 & 27 & 16 & 145.45 \\
\hline Balance Fertilizer application & 08 & 21 & 13 & 162.5 \\
\hline Weed Management & 17 & 28 & 11 & 64.70 \\
\hline Spacing \& Plant population & 07 & 22 & 15 & 214.28 \\
\hline Foliar Nutrition & 04 & 17 & 13 & 325.00 \\
\hline Recommended Insect pest management & 02 & 19 & 17 & 850.00 \\
\hline \multicolumn{4}{|c|}{ Overall Impact } & 283.03 \\
\hline
\end{tabular}

Table.5 Impact of Front Line Demonstration (FLDs) on horizontal spread of tomato hybrid

\begin{tabular}{|c|c|c|c|c|}
\hline \multirow[t]{2}{*}{ Variety } & \multicolumn{2}{|c|}{ Area (ha) } & \multirow{2}{*}{$\begin{array}{l}\text { Change in } \\
\text { Area (ha) }\end{array}$} & \multirow{2}{*}{$\begin{array}{c}\text { Impact } \\
\text { (\% Change }\end{array}$} \\
\hline & Before Demonstration & After Demonstration & & \\
\hline Arka Rakshak & 6.0 & 36.0 & 30.0 & 500 \\
\hline
\end{tabular}


$\mathrm{B}$ : $\mathrm{C}$ ratio was recorded to be higher under demonstration against control during all the years of study. Scientific method of tomato cultivation can reduce the technology gap to a considerable extent, thus leading to increased productivity of tomato in the district which in turn will improve the economic condition of the growers. Moreover, extension agencies in the district need to provide proper technical support to the farmers through different educational and extension methods to reduce the extension gap for better tomato production in the district.

The results of improved technological intervention brought out an increase in yield of tomato to the tune of 28.47 to $71.92 \%$. Improved package of practices can decrease the technology gap, thereby productivity of the crop can be increased. It was found that adoption of recommended hybrid of tomato by the farmers before demonstration was negligible, which increased by $222.22 \%$ after demonstration. Transplanting in raised bed technique was increased $145.45 \%$ due to intervention through FLD. The overall adoption level of tomato production technology was increased by about 283 percent due to FLD conducted by KVK Seoni (Table 4). Similar findings in case of jute crop were reported by Chapke (2012) and Mahale et al., (2016). In present study, efforts were made to study the impact of FLDs on horizontal spread of tomato hybrid. Data in Table 5 indicated that FLD organized on tomato crop helped to increase area under recommended hybrid. There was significant increase in area horizontally from 6.0 ha to 36.0 ha under hybrid of tomato, therefore the study conclude that FLDs organized by KVK, Seoni made significant impact on horizontal spread of this technology. Therefore, target oriented training programme on improved vegetable production technology along with multiple demonstrations is required to enhance level of knowledge and skills of growers which ultimately lead to adoption of technologies. Tomato cultivation and adoption of new technologies enhanced vegetable consumption nutritional security and overall livelihood security of the district.

\section{References}

Chapke, R.R. (2012). Impact of Frontline Demonstrations on Jute (Corchorus olitorius). Journal of Human Ecology, 38 (1): 37-41.

Dayanand, VRK. and Mehta, SM (2012). Boosting mustard production through front line demonstrations. Indian Res $\mathbf{J}$ Ext Edu 12 (3): 121-123.

Katare, Subhash, Pandey, S.K. and Mustafa, Mohd. (2011).Yield gap analysis of rapeseed mustard through front line demonstration. Agric. Update 6: 5-7.

Mahale, M., Patil, S. and Chavan, A. (2016). Impact of FLD Intervention on Yield, Adoption and Horizontal Spread of Oilseed Crops in Konkan, Indian Journal of Extension Education, 52 (3\& 4):79-83.

Mishra, D.K.et al., (2009). Impact of front line demonstration on yield enhancement of potato, Indian Res. J.Ext.Edu 9 (3): 26-28.

NHB (2017) Indian horticulture database, National Horticulture Board, Ministry of Agriculture, Govt. of India.

Prasad C., Choudhary B.N. and Nayar B.B. (1987) First Line Transfer of Technology Project, ICAR, New Delhi pp87 15 (5): 11-13.

Samui SK, Maitra S, Roy DK, Mandal AK, Saha D (2000) Evaluation on front line demonstration on groundnut. J Indian Soc Costal Agric Res 18:180-183.

Singh A, Singh L and Prasad R (2002). Effect of front line demonstration on pulse yield during different seasons in Uttar Pradesh, Indian Res. J. Ext.Edu 2 (2): 64-66. 
Singh., D.V., Mukhi, S.K. and Mohapatra, M.R. (2016) Yield Gap Analysis of Toria (Brassica campestris) through Front Line Demonstration in
Kandhamal District of Odisha, Indian Journal of Extension Education, 52 (3\& 4), 167-170.

\section{How to cite this article:}

Singh, N.K., Mrigendra Singh, Sharad Bisen and Bhandarkar, A.P. 2018. Yield Gap Analysis, Economics, Adoption and Horizontal Spread of Tomato Cultivation through Front Line Demonstration in Seoni District of Madhya Pradesh, India. Int.J.Curr.Microbiol.App.Sci. 7(05): 2720-2726. doi: https://doi.org/10.20546/ijcmas.2018.705.315 